\title{
Value development at Online Distance Learning university
}

\section{Malgorzata Pankowska ${ }^{1}$}

\author{
${ }^{1}$ University of Economics, Information Systems Department, pank@ae.katowice.pl
} Katowice Poland

Received 10 September 2006; accepted 11 November 2006

\begin{abstract}
The paper covers different interpretations of Online Distance Learning (ODL) organization and explanation of current managerial theories that have impact on its development. In the paper, two research methods have been applied i.e. case studies and literature interpretation. First, author presents case studies and delivers characteristics of the four case studies of ODL institutions project development. In the main part of the paper, basing on the case studies and literature studies, author delivers the model of value creation and sharing at ODL university. Author argues that ODL university value creation demands a completely new approach towards educational processes. Their development requires knowledge and relationship management, IT architecture development, resource management by contracts, standardization for controllability, compatibility and interoperability. The paper contains a review of standards applicable in online distance education organizations. Author concludes that proposed value development model is important for ODL organization strategy management.
\end{abstract}

Key words: Online Distance Learning, Value Development, Strategy Management 


\section{Online Distance Learning university theoretical background}

Nowadays, institutions try to virtualize a part or the whole of their operations opting for the ad hoc implementation of Information Communication Technology (ICT) solutions. Online Distance Learning (ODL) universities as a distinct organizational form can be viewed as loosely coupled systems tied together by a combination of joint aspirations, conversational interactions, collaborating and occasionally competing communities of practices [1], [6], [17], and [50]. Generally speaking, the ODL university is an institution free from the geographical confines of the campus, using the new communication technologies to connect learners, potential learners, teachers, researchers, research founders, IT professionals for Learning Management Portal administration for the online courses contents management and virtual university administrators for using management systems for controlling educational processes in a flexible ever-changing network organization. ODL university is a certain form of virtual organizations [14], [19], [24], [26], [33]. Some ODL universities are created within existing universities, while a wide range of new institutions and collaborative ventures are being set up independently. They follow the development process typical for e-Commerce organizations [47]. Plant [47] considered the Internet companies from three different viewpoints:

- The new organization, which was born on the Internet in the e-Commerce marketspace. An organization is attempting to create an entirely new product or service concept such as America Online, where a new technology is deployed.

- Established organizations traditionally positioned in the offline market space moving to the Internet. They answer the demands of clients, who want everything now, without delay, in whatever place and time. The Internet and mobile devices are time compression mechanisms of learning, viewed in a more traditional manner as the engines of productivity growth. A company is attempting a new execution of an existing product or service previously available to the market in an offline form, such as eBay, which via the Internet, delivers an ancient transactional method of trade, that of the auction house.

- Those organizations that are coming together in a new organizational form - e-Consortia - whose aim is to leverage the unique strengths associated with each company and partner through the virtual structure of an online organization. E-Consortium is a set of organizations forming a project to create an online entity in an area in which their individual strengths can be better leveraged to create future value.

The ODL university can develop in one of the three mentioned above ways. The new tendencies emerging in eCommerce world concerning the university education are significantly influencing e-Learning:

- $\quad$ The shift from graduating-oriented studying to learning-oriented studying

- $\quad$ The shift from student to learner, so the learning process is more cooperative than competitive

- $\quad$ The shifts from expertise in a domain to teaching beliefs. One teacher may have diverse beliefs from another and the different actors (students, peers, and teachers) may have diverse beliefs about the domain and teaching methods

- $\quad$ The shift from the four-year graduate program to lifelong learning

- $\quad$ The shift from the dominance of the teachers' roles to student-centred pedagogical thinking

- Decrease in the cost of technologies and services

- $\quad$ Rapid growth and advancement of the Internet technologies

- Growing political commitment at European Union level to promote the widespread use of educational technologies through partnership between institutions and businesses [6], [20], [30], [39].

According to the Bologna Declaration, the key factors to greater consistency and compatibility between courses in different education systems comprise the adoption of a system of easily readable and comparable degrees, the adoption of a system essentially based on two main educational cycles, the establishment of a system of credits (European Credit Transfer and Accumulation System - ECTS system) as a proper means of promoting the most widespread student mobility, the promotion of European cooperation in quality assurance with a view to developing comparable criteria and methodologies, the promotion of students and staff mobility and emphasizing European dimension in higher education. Bologna Declaration aims to promote the convergence of different systems to improve the transparency and compatibility of different courses, degrees and diplomas. The resulting project Tuning Educational Structures in Europe is at the heart of the Bologna-Prague-Berlin-Bergen process. The project focuses not on educational systems, but on educational structures and content of studies [25], [58]. Whereas, educational systems are primarily the responsibility of governments, educational structures and contents are that of higher educational institutions. 


\section{Research method explanation}

Nowadays in Europe, the educational system reforms encourage further discussion on the comparability of curricula in terms of structures, programs and actual teaching as well as inseparable linking credits and learning outcomes, expressed in terms of competences. In the reform process the required academic and professional profiles and needs of society should also play an important role.

Step by step, universities have been re-engineered towards ODL organizations. As a less risky approach they apply blended methodology in education and develop university services online. They include e-libraries, instructional networking and computing, media services, the campus course catalogue and schedule, multimedia courseware production. Many projects within EU countries are now developed aiming to propagate the positive ideas of virtual education among students. At some universities, the projects cover many additional supplement courses supporting basic offline teaching activities. They are to encourage students to learn online and to persuade teachers that the new educational forms are valuable and effective. Generally, ODL projects are based on agreements among involved universities; however, the converging service centre is established to ensure educational platform maintainability.

The preparation of model of value development at ODL universities was based on careful monitoring of ODL projects in which author is involved. However, in the paper two research methods have been applied i.e. case studies and literature interpretation. Author recognized that acceptance only case studies as a research method for the formulation of the value development model is not sufficient, because of a lot of weaknesses of provided so far online distance education. Therefore, the literature studies of value interpretation and value creation model modification were added.

The comparative study of the four cases i.e. ODL projects is included in table 1. All these ODL projects concern education on academic level for full time or part-time students of traditional universities. Projects do not concern training for practitioners. Proposed and disseminated by the universities within the projects, courses are oriented to increase knowledge and develop intellectual capital through providing basic theories in economics. The first case study concerns ODL university that includes providing online courses for students of five "brick and mortar" universities in one country. The second case is about virtual education project developed by teaching staff of five universities in Europe. Case 3 is the continuation of project B, where new teaching methods, new course materials and quality standards have been applied. Project D concerns only one university, where, for students travelling a lot, online courses were provided to enable them studying wherever they are. The courses and didactic materials online are supplemental to the traditional "brick and mortar" teaching.

\begin{tabular}{|c|c|c|c|c|}
\hline $\begin{array}{r}\text { Project } \\
\text { Comparison criterion }\end{array}$ & $\begin{array}{c}\text { Project A } \\
\text { Case } 1\end{array}$ & $\begin{array}{l}\text { Project B } \\
\text { Case } 2\end{array}$ & $\begin{array}{c}\text { Project C } \\
\text { Case } 3\end{array}$ & $\begin{array}{l}\text { Project D } \\
\text { Case } 4\end{array}$ \\
\hline Organizational form & $\begin{array}{l}\text { National consortium } \\
\text { consisting of five } \\
\text { universities within } \\
\text { one European } \\
\text { country }\end{array}$ & $\begin{array}{l}\text { International } \\
\text { consortium } \\
\text { consisting of five } \\
\text { universities from } \\
\text { different European } \\
\text { countries }\end{array}$ & $\begin{array}{l}\text { Continuation of } \\
\text { project B. } \\
\text { International } \\
\text { consortium } \\
\text { consisting of five } \\
\text { universities from } \\
\text { different European } \\
\text { countries }\end{array}$ & $\begin{array}{l}\text { Education moved to } \\
\text { the Net for one } \\
\text { country students } \\
\text { dispersed within } \\
\text { different European } \\
\text { countries }\end{array}$ \\
\hline $\begin{array}{c}\text { Phase of project } \\
\text { development }\end{array}$ & $\begin{array}{l}\text { Project results } \\
\text { exploitation. } \\
\text { ODL activities } \\
\text { realisation }\end{array}$ & $\begin{array}{l}\text { Project results } \\
\text { exploitation. } \\
\text { ODL activities } \\
\text { realisation }\end{array}$ & $\begin{array}{l}\text { Project } \\
\text { implementation }\end{array}$ & $\begin{array}{l}\text { Project results } \\
\text { exploitation. } \\
\text { ODL activities } \\
\text { realisation }\end{array}$ \\
\hline Target market & $\begin{array}{l}\text { Well established } \\
\text { target market. } \\
\text { Students recruited } \\
\text { from traditional } \\
\text { universities within } \\
\text { one country }\end{array}$ & $\begin{array}{l}\text { Students recruited } \\
\text { from different } \\
\text { countries, however, } \\
\text { only the general } \\
\text { outline of the target } \\
\text { market }\end{array}$ & $\begin{array}{l}\text { Students recruited } \\
\text { from different } \\
\text { countries, however } \\
\text { only the general } \\
\text { outline of the target } \\
\text { market }\end{array}$ & $\begin{array}{l}\text { Well established } \\
\text { target market. } \\
\text { Students continue } \\
\text { learning online after } \\
\text { migration to another } \\
\text { country, city or } \\
\text { university }\end{array}$ \\
\hline $\begin{array}{c}\text { Number of students } \\
\text { involved in ODL }\end{array}$ & 60 & 20 & 20 & 20 \\
\hline Duration & 3 semesters & 1 semester & 1 semester & 2 semesters \\
\hline Course language & Polish & English & English & English \\
\hline
\end{tabular}

Table 1: Comparative analysis of ODL projects 


\begin{tabular}{|c|c|c|c|c|}
\hline $\begin{array}{r}\text { Project } \\
\text { Comparison criterion }\end{array}$ & $\begin{array}{l}\text { Project A } \\
\text { Case } 1\end{array}$ & $\begin{array}{l}\text { Project B } \\
\text { Case } 2\end{array}$ & $\begin{array}{c}\text { Project C } \\
\text { Case } 3\end{array}$ & $\begin{array}{l}\text { Project D } \\
\text { Case } 4\end{array}$ \\
\hline Strategy objectives & $\begin{array}{l}\text { Providing attractive } \\
\text { in form, innovative } \\
\text { and modern courses } \\
\text { for students within } \\
\text { one country. } \\
\text { Courses must be } \\
\text { novel, unique, } \\
\text { different and } \\
\text { supplemental to } \\
\text { courses delivered } \\
\text { offline }\end{array}$ & $\begin{array}{l}\text { Creating the } \\
\text { community of } \\
\text { students and } \\
\text { practitioners } \\
\text { involved in special } \\
\text { problems e.g. } \\
\text { e-Commerce } \\
\text { development }\end{array}$ & $\begin{array}{l}\text { Creating the } \\
\text { community of } \\
\text { students and } \\
\text { practitioners } \\
\text { involved in special } \\
\text { problems e.g. } \\
\text { e-Commerce } \\
\text { development }\end{array}$ & $\begin{array}{l}\text { Providing traditional } \\
\text { courses content } \\
\text { online to supplement } \\
\text { offline learning }\end{array}$ \\
\hline Teaching methods & $\begin{array}{l}\text { Providing online } \\
\text { multimedia course } \\
\text { materials. } \\
\text { Deployment of } \\
\text { online games. } \\
\text { Exchanging roles of } \\
\text { students and } \\
\text { teachers }\end{array}$ & $\begin{array}{l}\text { Providing online } \\
\text { multimedia course } \\
\text { materials. } \\
\text { Blended learning }\end{array}$ & $\begin{array}{l}\text { Deployment of } \\
\text { online games. } \\
\text { Blended learning }\end{array}$ & $\begin{array}{l}\text { Providing online } \\
\text { textual course } \\
\text { materials. } \\
\text { Blended learning }\end{array}$ \\
\hline $\begin{array}{r}\text { Verification of } \\
\text { students' } \\
\text { knowledge }\end{array}$ & $\begin{array}{l}\text { Evaluation of } \\
\text { students' essays, } \\
\text { projects, and tests } \\
\text { delivered online. } \\
\text { Monitoring students' } \\
\text { activities in forums. } \\
\text { ECTS system } \\
\text { implemented }\end{array}$ & $\begin{array}{l}\text { Monitoring students' } \\
\text { activities in chat } \\
\text { rooms and forums. } \\
\text { Exams offline }\end{array}$ & $\begin{array}{l}\text { Monitoring students' } \\
\text { activities in chat } \\
\text { rooms and forums. } \\
\text { Monitoring game } \\
\text { results. } \\
\text { Exams offline }\end{array}$ & $\begin{array}{l}\text { Exams offline. } \\
\text { ECTS system } \\
\text { implemented }\end{array}$ \\
\hline $\begin{array}{c}\text { Critical success } \\
\text { factors }\end{array}$ & $\begin{array}{l}\text { Project leadership. } \\
\text { IT architecture, } \\
\text { strategy and } \\
\text { contracts } \\
\text { management. } \\
\text { Learning } \\
\text { Management } \\
\text { System } \\
\text { administration. } \\
\text { Controlling students' } \\
\text { work and progress. } \\
\text { Attractiveness and } \\
\text { novelty of courses' } \\
\text { content. } \\
\text { Marketing and } \\
\text { dissemination of } \\
\text { project results }\end{array}$ & $\begin{array}{l}\text { Project leadership. } \\
\text { IT architecture and } \\
\text { contracts } \\
\text { management. } \\
\text { Attractiveness and } \\
\text { novelty of courses' } \\
\text { content. } \\
\text { Marketing and } \\
\text { dissemination of } \\
\text { project results }\end{array}$ & $\begin{array}{l}\text { Project leadership. } \\
\text { IT architecture and } \\
\text { contracts } \\
\text { management. } \\
\text { Project quality } \\
\text { management. } \\
\text { SCORM standards } \\
\text { implementation. } \\
\text { Marketing and } \\
\text { dissemination of } \\
\text { project results }\end{array}$ & $\begin{array}{l}\text { Comfort of learning } \\
\text { for nomadic } \\
\text { students. } \\
\text { Compliance of } \\
\text { online and offline } \\
\text { courses. } \\
\text { IT architecture and } \\
\text { contracts } \\
\text { management }\end{array}$ \\
\hline
\end{tabular}

Table 1: Comparative analysis of ODL projects (continuation)

In all the cases, the Learning Management Systems have been implemented and exploited. The didactic materials as multimedia files are accessible only to authorized students. Protection through login and password is applied. According to students, the strong weakness of ODL is lack of direct (Face-to-Face, F2F) communication. In three projects, blended learning methodology has been applied, so it includes offline contact that is very helpful to increase trust, because the people are conscious to whom they address their questions and answers. In all four projects, the communication media cover email, forums, and chat rooms. Blended learning utilized in some cases comprises advantages and disadvantages of offline and online learning [43]. Then, communication among students and teaching staff is F2F as well as via emails, chat rooms and forums. Students work in "brick and mortar" laboratories and they browse the manuals in the Internet. Evaluation of students' skills and level of knowing the course materials has been done directly during the verbal exams and indirectly basing on their essays, projects and test results delivered electronically or non-electronically. 


\section{Theoretical considerations on values in e-Learning}

Since e-Learning is a product/service package, it is necessary to identify those aspects of the service that are critical to customer's (i.e. student's) perceptions. Knowing what customer expects is a necessary but not sufficient condition for satisfying customers who will return for repeat service and possibly provide comments to their peers. The principal features important to customers include reliability, responsiveness, respect, engagement, empathy, mutual understanding, acceptability of questions and answers. Generally speaking, online learning service providers have little opportunity to impress customers with their facilities and personnel. The only information most customers of Web sites have available for learning is what they see in their computer monitor. Therefore, attractive Web site design and presentation of multimedia course data is of paramount importance for e-Learning Web site developers. Developers must do all they can to ensure a positive impression of the ODL organization and its teaching staff. However, it is still not sufficient for success of ODL institution. Virtual education system cannot rely on providing Commercial Of The Shelf (COTS) packages of courses. Although, set of typical characteristics of ODL environment covers standardization of course programs and contents, multimodal communication, integration of multimedia of didactic materials and customization of educational services, the core value of distance education is not in delivered contents, but in appropriate distance care of students (e-Coaching, e-Tutoring). Neglecting to be online on time by a tutor will reduce student's engagement and education quality. Knowles argues that adults need explanations of why they learn. They want to control and take responsibility for educational process [39], [50]. Development of online distance learning systems for adults is realized in circumstances of strong competitiveness of virtual education institutions. Such a situation creates the necessity to persuade students that learning will bring them personal benefits. Coming into e-Education domain a person is involved in psychological contract - unique and informal set of rules and conditions. A special, unwritten agreement exists among students and teaching staff. In opposite to economic contract, the first one covers expectations concerning non-material aspects of educational processes. The focus is on relations not on transaction of buying or selling educational services, although breaking the psychological contract can have economic consequences. Students expect a transfer of knowledge, a valuation of knowledge and opportunities to create trust and ensuring persuasion that they will succeed in education process [5], [36]. On the other side, teaching staff expects that students will behave according to pre-specified rules and that they will be creative in cognitive educational processes.

This approach is consistent with the approach of Piaget [46]. Piaget argues that interactions among individuals are understood as exchanges of services among them, involving not only the realization of services by some individuals on behalf of others, but also the evaluation of such services, from various points of view by every individual involved. The evaluation of a service by an individual is done on the basis of a scale of so-called exchange values that are of a qualitative nature, since such values express subjective evaluations [46]. The scope and scale of exchange values are determined by culture and social rules within a community. The social rules may be enforced by authorities (and contracts) that have the capacity to force the learners to follow the rules.

\section{Value creation model proposal}

Value is a preferred combination of benefits compared with acquisition costs [2], [4], [59, [60]. From an organization's perspective, the response to customer expectations is a value proposition, which is a statement of what value is to be delivered to the customer. Externally, the value statement is the means by which the organization positions the offer to the target client. Internally, the value statement identifies how the value is to be produced, communicated, delivered and maintained. The internal statement specifies processes, responsibilities, volumes and costs to be achieved if the customer and each of the other e-Learning project stakeholders are to receive satisfaction.

E-Learning value is subjectively assessed by students, who base their evaluation of value on their perceptions of the usefulness of the course. Value in use is the consumer value delivered in response to identified opportunities [45]. It represents a package of benefits comprising the quantitative attribute, price and qualitative features that often are specific to the particular customer or customer segment. Exchange value is realized when the product is sold. It is the amount paid by the buyer to the service producer for the perceived use value. Exchange value, the price realized and costs of producing the product and service determine the profit made [2], [3].

Within ICT sector value-driven management could be helpful to ensure that the commercially necessary and sufficient service levels are provided for users [2], [28], and [29]. Even when e-Learning projects succeed, there are often huge doubts about the realization of promised benefits. The management of e-Learning is to maximize the value derived from ICT investments. Value management as a concept goes way back to the 1940s and 1950s when Lawrence D.Miles pioneered the value analysis technique. He was primarily concerned with product cost reduction. Since then, value management has enlarged its view to also address increasing performance and improving commercial outcomes [41], [49], [52].

The root principle of value management is a continuous awareness of value for the organization, establishing measures or estimates of value, monitoring and controlling them [9], [60].

Activities creating values for customers constitute a value creating system. These activities are carried out using sets of human tangible and intangible resources. They are linked by flows of material, information, financial resources and 
influence relationships. Final customers not only receive and consume the values created but can also participate in value-creating activities. Realization of the idea that the teacher is not the expert and the exchange of roles for teachers and students is possible allows learners to create values in educational process.

Value development model is a certain framework, which construction allows researchers to:

1. Remove emotion in analyzing essential determinants of core values

2. Provide structure for analyses and allows to prioritize proactively problems that should be solved

3. Manage change in strategy development process and continuously go from lower to upper level of quality assurance

4. Educate uniformly about essential phenomena dependences

5. Enhance stability of e-Learning organizations

6. Enable comparability and compatibility of ODL institutions

The value creation model for ODL university is presented in Figure 1. It is based on the idea developed by Walters [60].

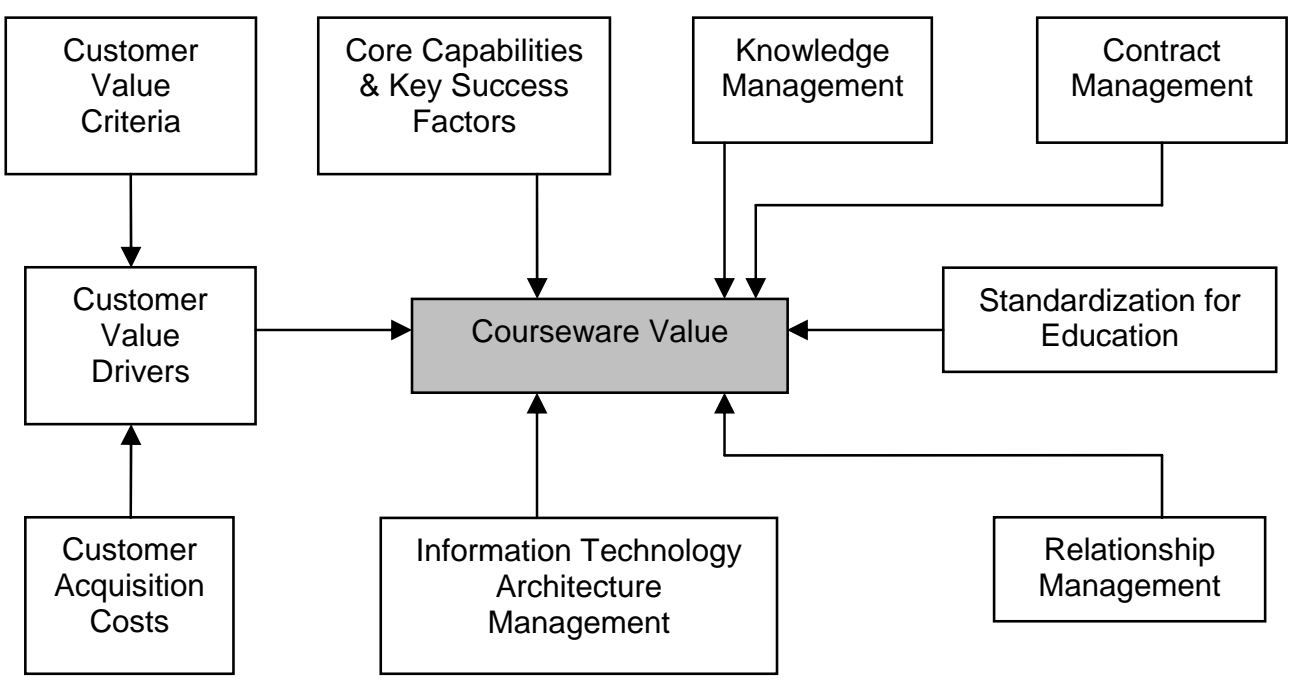

Figure 1: Value development model in Online Distance Learning university

In the value creation model the customer value criteria are rather differentiated. Students expect curricula's relevance, courseware quality and academic and administrative support, academics - students' engagement in educational process and in courses' development support. Administration is interested in costs and capacities planning. Other business environment institutions expect strong reputation, relevance of courses' curricula to the market expectations, high quality of education and commitment. The university should attempt to enhance the benefits they perceive as important to achieve maximum satisfaction and where possible, work with partners to reduce the cost customers incur when acquiring an educational product. Core capabilities comprise distinctive capabilities (i.e. specialist curricula and delivery systems, strong marketing and market representation) and reproducible capabilities (i.e. student enquiry, application and administration facilities). Key success factors are current and quality curricula, high quality, and professional and customer-centred information systems supporting ODL university administration [40].

The courseware value proposition should clarify the attributes of products and services that are available to customers. This identifies the responses to customers' expectations. It also identifies the roles and tasks of employees, partners and other intermediaries involved in the value creation and value dissemination among learners. Value drivers are features that customers are prepared to pay for. Such features may be generally expressed as:

- $\quad$ Security: warranties, price guarantees 
- Convenience: availability

- Performance: quality features that enhance the customer's own market advantage, time advantage

- Economy: relative price advantage - initially or over the life cycle of the product/service

- $\quad$ Aesthetics: Web portal design excellence

- $\quad$ Reliability: durability in use, courseware maintaining and modernization.

In online distance education, knowledge management relates to developing an understanding of markets, customers' needs and decision process managers, opportunities and threats, marketing channels, and brand position [8], [13], [42], [51]. It also relates to understanding products and the ability to bring new products, which represent customer needs, into the market in a timely fashion. It is about the extent to which innovation and development are valued.

Relationship management covers the ways the universities have worked together and opened up their own departments and educational processes to the scrutiny of all. Typically, universities have always had a multitude of partnerships internationally; offshore providers, other universities and colleges. In many instances these have been long standing and successful relationships. Universities are facing the situation where more and more students are being recruited via the Internet. It is very cheap, however, prospective students will seek out information resources from the university and use these to help select a destination, but are likely to look for the security of assistance from a university agent.

\subsection{Information Technology Architecture Management}

Architecture is progressively seen not just as a tactical instrument for designing an organization's systems and processes but as a strategic tool for enterprise governance [35], [38], [44]. ODL university architecture is expressed in the following four subsidiary architectures:

- Institutional Architecture, that involves the ODL university mission, strategy, courseware components, organizational structure, educational process models, business functions (e.g. payments transactions)

- Information Architecture (also called Data Architecture), that reveals who requires what information to achieve their mission and how this information is made available

- $\quad$ Application Architecture (also called Functional Architecture), that involves the applications that are necessary for the ODL university mission and the information needs. It also gives insight into the ODL university departments, divisions or teams differently responsible for the courses

- $\quad$ IT Architecture that shows which IT services are necessary for the applications as well as software, hardware and network products [35].

ODL university architecture identifies the organization of data, applications and infrastructure and how they are interrelated both statically as well as during run-time execution within Learning Management System (LMS).

\subsection{Contract Management}

At ODL university the dissemination of knowledge, the distribution of services and the provision of access to different resources are based on contracts and agreements. Service Level Agreements (SLAs) are clear descriptions of activities, as performed by a supplier under orders from a recipient. To some degree of detail, the SLA describes when, how and where the activities are executed [27], [55]. SLAs are aimed at creating certain level of expectation. They record the intention of organizations for cooperating in the long run.

The SLA is positioned in the middle, between the institutional contract and the more operationally focused administrative procedures. The SLA is signed for a shorter period of time than the contract is. The SLA includes agreements on the quality, the quantity and the costs of the facilities.

At ODL university, the contents of the sourcing contracts may include the elements of various contracts provided for in law. It may contain elements of a sales contract, an agreement for provision of services and a data processing agreement. In the part of the contract dealing with purchase and sale, it is indicated which objects are handed over. A second part of the sourcing contract deals with the services to be delivered. This part describes the services, deals with the scope of the provision of services and the way in which one deals with work. ODL university partners, for their own interests' protection, should sign the contract for cooperation, usually for a period longer than two years. The central provision of services is further elaborated in agreements. ECTS (European Credit Transfer System) Student Application Form and ECTS Learning Agreement have been developed for mobile students, who will spend a limited study period at a university in a foreign country [58]. The Learning Agreement contains the list of course 
units or modules which the student plans to take. For each course unit the title, the code number and the ECTS credit are indicated. It guarantees the transfer of credit for courses offline passed successfully by the student. The ECTS system should be modified, because this agreement does not exclude courses delivered online.

\subsection{Standardization for ODL}

Standards play a prominent role in many systems that are characterized by interaction and interrelatedness [12], [34]. In information systems, standards provide compatibility and are a prerequisite for collaboration benefits [61]. Weitzel [61] uses the term standard to refer to any technology or product (software, hardware) incorporating technological specification that provides compatibility. Products are said to be compatible when their design is coordinated in a way that enables them to work together. Compatibility standards enable users to participate in networks that allow them to share databases, have access to large selection of compatible software, exchange documents and communicate directly. The network effects in virtual education markets mainly originate from two different areas: the need for compatibility to exchange information and the need for complementary products and services.

Standardization activities extend over a wide variety of areas. The activities of standardization organizations such as ISO, ANSI or DIN can confirm this. Standards set by these types of organizations are often referred to as norms [34].

Standardized approach to educational process enables mixing and matching content from multiple sources. It enables the development of interchangeable content that can be reused, assembled and disassembled quickly and easily. It makes it possible to verify the view that the learning technology investments are wise and risk adverse [21].

Whether it is the creation of content libraries or learning management systems, accredited standards will reduce the risk of making large investments on learning technologies. Accredited standards assure that the investment in time and intellectual capital can move from one system to the next. Such standards are generic for distance learning education not only on academic university level, but also for postgraduate students, advanced professional training and high schools, so they can be applied as supplement to university education systems. Organizations responsible for the development of computer-based training standards are as follows:

- $\quad$ The Advanced Distributed Learning (ADL) Initiative (Site 1). The ADL Initiative developed the concept and implementation of ADL specifications and guidelines such as the Shareable Content Object Reference Model (SCORM) to define relations of course components, data models and protocols so that learning content objects are shareable across systems that conform to the same model. The SCORM contains a collection of specifications adapted from global specification bodies and consortia to provide a comprehensive suite of eLearning capabilities, enabling interoperability, accessibility and reusability of Web-based learning content.

- $\quad$ The ARIADNE Foundation (Site 2) that is involved in standardization activities performed under auspices of the IEEE LTSC Committee. In this context, ARIADNE agreed to collaborate with the US-funded EDUCAUSE IMS Project, in view of reaching an educational metadata set that would be widely acceptable. ARIADNE has built the Knowledge Pool System: a Europe-wide distributed repository for pedagogical documents, with associated indexation and query tools.

- $\quad$ The Australian Consortium EdNA (Education Network Australia) (Site 3).

- $\quad$ The Aviation Industry CBT (Computer Based Training) Committee (AICC) (Site 4) is an international association of technology-based training professionals. The AICC develops guidelines for aviation industry in the development, delivery and evaluation of CBT and related training technologies.

- $\quad$ BAOL Quality Mark (Site 5) provides a Quality Assurance system using internal self-assessment and external verification of the distributed products and services for open and flexible learning. It is based on a framework of criteria adapted from the Business Excellence Model promoted by the British Quality Foundation (BQF) and cross referenced against established Open Learning Guides so as to be relevant to all aspects of open learning provision and use.

- CEN (Comité Européen de Normalisation)/ The ISSS division (Information Society Standardization System) Workshop on Learning Technology (Site 6).

CUBER project (Site 7). The aim of the CUBER project is to build an adaptive high-precision information system for information technology (IT) courses of European universities. Special emphasis will be placed on distance learning courses and other methods of "just-in-time and just-in-place learning". However, the perspective of the CUBER approach goes beyond the partners or the present consortium and beyond the domain of IT courses. It also includes supporting the search for higher education courses matching specific needs of users, making courses comparable through standardized metadata descriptions, combining courses from heterogeneous sources to coherent packages, building the grounds for a Federated European Virtual University. The purpose of metadata in CUBER is to facilitate search, comparison and selection of study courses, packages and programs offered by the course providers, i.e. universities and other educational institutions. 
- $\quad$ DESIRE - Development of a European Service for Information on Research and Education (Site 8).

Dublin Core Metadata Initiative. The Dublin Core is a metadata element set intended to facilitate discovery of networked electronic resources (Site 9). The Dublin Core metadata set is emerging as de facto the metadata standard for facilitating the discovery of both physical and online resources in a networked environment such as the Internet. One of the aims of the Dublin Core Initiative is to facilitate interoperable discovery between online communities. Governments, geospatial information providers, libraries, museums and the education sector are all using Dublin Core to improve discovery of information within their communities. By using the same metadata standards these communities can also more easily discover each other's resources. The Dublin Core Metadata Initiative is an open forum engaged in the development of interoperable online metadata standards that support a wide range of purposes and business models [11.]

- $\quad$ ETB quality research project (Site 10). Its aim is to build a Web educational resource metadata networking infrastructure for schools in Europe. Provided in eight languages the ETB thesaurus is a documentary tool aimed to facilitate indexing and searching processes in two contexts. The first is a metadata infrastructure for information exchange, connecting European educational repositories that have their own indexing systems and documentary languages. The second is native repositories characterized by a European dimension from the very beginning.

- Gateway to Educational Materials (GEM) is a consortium effort to provide "one-stop, any-stop" access to the substantial, but uncatalogued collections of Internet-based educational materials available on various federal, state, university, non-profit, and commercial the Internet sites. It is a consortium of $300+$ organizations and individuals who support the goals and mission of the GEM Project (Site 11).

- $\quad$ The IEEE Learning Technology Standards Committee (LTSC) (Site 12) is working under the auspices of the IEEE Computer Society Standards Activity Board to develop accredited technical standards, recommended practices and guides for learning technology.

The IMS (Instructional Management System) as a project within the National Learning Infrastructure Initiative of EDUCAUSE (Site 13). The scope of IMS specifications, broadly defined as distributed learning includes both online and offline settings, taking place synchronously and asynchronously. This means that the learning contexts benefiting from IMS specifications include the Internet-specific environment (such as Web-based course management system) as well as learning situations that involve offline electronic resources (such as a learner accessing learning resources on a CD-ROM).

The ISO and International Engineering Consortium Joint Technology Committee (ISO/IEC JTC1) (Site 14) has started a Standards Committee (SC36) on Information Technology for Learning, Education and Training. SC36 work program is for standardization in the field of information technologies for learning, education and training to support individuals, groups or organizations and to enable interoperability and reusability of resources and tools. Work Group 1 "Vocabulary" is developing domain specific terminology standards and will be harmonized with the existing ISO/IEC 2382 series for Information Technology vocabulary. Work Group 2 "Collaborative technology" is developing several standards to support the IT aspects of learner collaboration. These standards include the collaborative workplace (data collection and reuse for collaborative environments), learner-to-learner interactions (peer-to-peer and group) and agent-to-agent interactions (agent-based interfaces in collaborative environments). Work Group 3 "Learner information" is developing standards that specify data models, bindings, codings, APIs, protocols for data interoperability and data exchange of information associated with learners (e.g. grades, preferences, abilities, objectives, portfolios, peers). Work Group 4 is for Management and Delivery. Work Group 5 "Quality Assurance and Descriptive Frameworks" is to describe and characterize processes, components and attributes related to the quality and architecture of IT-supported environment in the field of learning, education and training.

Promoting Multimedia access to Education and Training in European Society (PROMETEUS) (Site 15). PROMETEUS is an open initiative sponsored by the European Commission with the aim of building a common approach to the production and provision of e-Learning techniques and content in Europe. The objectives of the PROMETEUS signatories are to improve the effectiveness of cooperation between education authorities and establishments to foster the development of standards for digital multimedia learning content and services, to give the global dimension of cooperation among education institutions and to include the user needs' concerning ICT in the education and training sector.

Reusable Learning Objects (RLOs) by Universities' Collaboration in e-Learning (UCeL) (Site 16) is a pragmatic and pioneering project, engaged in defining a learning object as an interactive online resource based on a single learning objective and comprising a stand-alone collection of 4 components: presentation, activity, assessment and links. According to Boyle, a learning object is defined as any entity, digital or non-digital, that may be used for learning, education and training (Boyle, 2003). Generative learning objects (GLOs) can be adapted by local tutors to suit their individual teaching and learning needs. UCeL recognizes that individuals, not institutions, collaborate and that the first step to successful reuse is by empowering and sustaining a community of practice. The creation of GLO is divided into two parts, the building of the Learning Object Template and the addition of 
the subject specific content. The Learning Object Template will contain the deep structure or the learning design. Once a Learning Object Template has been created, tutors can add different subject specific content, the surface structure, to produce many Learning Objects fit for purpose in their particular fields. Building the Learning Object Template will be similar to the approach currently used by UCeL in the production of RLOs. The second stage is the creation of Learning Objects for application in specific subject areas. Based on the Learning Object Template, software tools will automatically generate web-based forms that tutors and students will use to supply the subject specific content. This content will be automatically combined with the Learning Object Template to produce a finished Learning Object. After a further process of peer review, the Learning Object will be published [10].

There is a difference in the European and American way of standardization. Europeans tend to find solutions on a governmental basis and so several governmental institutions and organizations are founded to work in the area. In opposite to that, the Americans often work out of market-driven situations and are pluralistic. Different societies have contradictory educational systems (different school/university models) and therefore a divergent understanding of what specifications should handle, what is essential and what is unimportant. The development of a standard for metadata suited for school as a specification is partly based on learning objects, but adds several other schoolspecific elements.

\section{Findings on importance of value development model for strategy management}

Strategy of ODL university focuses on establishing defensible strategic positions by setting organizational scopes, acquiring or building assets and establishing a balanced and authorized set of priorities. Different interpretations of strategy development are presented in literature [37], [56], and [57]. Sometimes strategies are presented as emerging from the individual university's perspective. The following are key points for inclusion in setting strategy for the ODL university environment:

- $\quad$ Being aware of new university risk structures, including the new legal international regulations

- $\quad$ Developing strategy with a continual focus on creating value through innovation and modern software tools (i.e. innovative student -oriented learning methods enabling their creativity development)

- Transforming internal governance strategy to match the changing needs of the external and internal environments facing the university

- $\quad$ Making the strategy a continual process - evolving, linking new initiatives to achieve holistic results

- $\quad$ Sharing the knowledge required to govern the university effectively through use of a knowledge portal

- $\quad$ Managing knowledge for more effective communication and directly actionable outcomes.

Anyway, the strategy of ODL university must be driven by innovativeness. It must develop cognitive abilities of learners and encourage them to creativity and cognition. The value of innovation is the essence of strategy in virtual university's knowledge economy.

Values (what we believe in) are conventional tenets against which an enterprise measures the worthiness of its choices. They are core to vision. At an ODL university, managed as the extended institution, four perspectives are needed for the strategy roadmap:

- Didactic processes' improvement through IT management and knowledge management to ensure value creation

- Customer (i.e. learner) satisfaction increase particularly through relationship management

- $\quad$ Financial perspective - costs evaluation and budgeting

- Growth of network effects because of strong marketing and dissemination of the information about products i.e. proposed courseware [54].

The above approach is a modification of now the most popular proposal to measure corporate strategy success created by Kaplan and Norton [15], [22], [31], [32], [53], and [62]. ODL university is a collection of autonomous teaching departments and divisions constituting a heterarchical organization. As in traditional educational systems, ODL universities have the dilemma to preserve autonomy or reject it under the pressure of institutionalism. Institutional economics forces them to look at the interaction of law, economics and politics. It requires defining property rights and establishing governance arrangements [7], [16], [18], [23]. 
Informal, non-commercial and relatively non-political research and education organizations originate in the Internet. So, many times the valuable resources are placed outside the appropriate control of existing institutions. The governance problems can be solved through the development of new institutional arrangements (i.e. service agreements). At ODL university, governance structures are needed to deal with the complexity of the network relations and to ensure their implementation strategies. The universities have to combine flexible institutional arrangements, limited power and commitment of the participants. Having network policies, managers have to consider in what way values can be communicated to all network participants and how to ensure the internalization of these values. At ODL universities, product (i.e. courseware) must pass a minimum threshold of adoption to survive in the market and ensure return of investment. ODL university must resemble a network of distributed intelligence. However, for strategy realization, not only disseminated knowledge is important, but also relations among the students, tutors and administration staff. Within ODL university, some organizational paradoxes are observed, such as coexistence of authority and democracy, efficiency and creativity, and discipline and empowerment which stem from perceptions of opposing and interwoven elements. Cognitive conflicts facilitate cooperation by aiming criticism at tasks. Moreover, the board (i.e. university rectors) and executive committees can play a vital role in maintaining diversity by providing periodical assessments of teaching staff and educational needs. The ODL university governance comprises formal rules and norms as well as informal aspects such as culture and identity. Institutional arrangements and governance structures are needed to deal with the complexity of the network relations and to ensure the implementation strategies. The structural arrangements have to reflect the network strategy and the constraints resulting from the fact that the network participants are autonomous units i.e. students and teachers. They have to combine flexible institutional arrangements into the virtual community. Appropriate network policies encourage network participants to work together in order to enable the coordinating effect of network policies, content, as well as interpretation of rules and values that have to be communicated clearly. ODL managers have to consider in which way norms, values etc. can be communicated to all network participants and how to ensure the internalization of these values.

\section{Summary}

Analyses of four case studies concerning ODL universities lead to the conclusions that a lot ought to be done to perceive success of virtual education. The cases' monitoring was the inspiration to propose a model of value development. Proposed value development model should constitute the base for strategy of e-Learning formulation and management.

Online Distance Learning at contemporary universities is a new educational form to supplement or even substitute traditional education. Standardization of educational processes, clarification strategy and IT architecture are necessary to create values at universities as reliable institutions, which work to educate adults and to enable educational activities verifiability, compatibility and comprehensibility. Standardization enables transparency of educational activities, their compatibility and controllability. Relationship management, knowledge management and contract management for access to university internal knowledge resources and administrative services as well as IT architecture management are to be the essential for value creation at the university and value dissemination within its academic environment. ODL university is located in the Internet and accessible from different places so its brand strongly depends on its ability to create virtual community of students and teachers gathered together and around university knowledge repositories. The community creation and network effects are possible because of modern IT architecture and personal relationship development and maintaining among scholars.

Value development model is justified by the necessity to continuously reengineer or reconstruct educational institutions that have the problem of what values are to be delivered to people, taking into account the opportunity to utilize modern ICT and future integration with mobile learning. So far, a lot of ODL institutions have been established; therefore, sooner or later they must cope with the risk of being trapped typical for e-Business dotcoms some years ago. To avoid the trap, ODL institutions should work on value development model and e-Learning strategy (using Balanced Scorecard suggested by Kaplan and Norton). Strategy, distance learning vision and target market specification are necessary, because of tremendous competitiveness. So, design and implementation of e-Learning portal containing multimedia materials in COTS packages is not sufficient. ODL institutions require relationship management as well as knowledge and ICT management. Standardization of educational contents is a condition for knowledge sharing and mutual understanding. However, standardization does not ensure success in e-Education. Standards of university curricula ensure dissemination of the-state-of-the-art knowledge but the ODL university should also utilize the opportunities to launch unique and innovative projects, create and disseminate beyond-the state-of-the-art knowledge. Universities usually struggle with the dilemma to ensure creativeness and innovativeness of people and idiosyncrasy of explored knowledge or to ensure average level of didactic processes. Value model can be helpful to consider what university is really going to provide. Customization of e-Learning object would probably cause an additional cost, however, ODL universities should, as it is in other e-Commerce units, differentiate the e-Learning products or services and develop customers' segmentation. 


\section{ODL Standardization Websites}

Site 1: The Advanced Distributed Learning (ADL)

http://www.adlnet.org

Site 2: The ARIADNE Foundation

http://www.ariadne-eu.org

Site 3 The Australian Consortium EdNA (Education Network Australia)

http://www.edna.edu.au/

Site 4: The Aviation Industry CBT (Computer Based Training) Committee (AICC)

http://www.aicc.org/

Site 5 BAOL Quality Mark

http://www.baol.co.uk/qmwhat.htm

Site 6 CEN (Comité Européen de Normalisation)

http://www.cenorm.be

Site 7 Cuber project

http://www.cuber.net

Site 8 DESIRE - Development of a European Service for Information on Research and Education http://www.ukoln.ac.uk/metadata/desire/quality

Site 9 Dublin Core Metadata Initiative

http://dublincore.org

Site 10 ETB quality research project

http://www.en.eun.org

Site 11 Gateway to Educational Materials (GEM)

http://www.scitechresources.gov/Results/show result.php?rec=2538

Site 12 The IEEE Learning Technology Standards Committee (LTSC)

http://ieeeltsc.org/

Site 13 The IMS (Instructional Management System) project

http://www.imsglobal.org/

Site 14 The ISO and International Engineering Consortium Joint Technology Committee (ISO/IEC JTC1) http://jtc1sc36.org/

Site 15 Promoting Multimedia access to Education and Training in European Society (PROMETEUS) http://eml-sig.eulearn.net/

Site 16 Universities' Collaboration in e-Learning (UCeL)

http://www.ucel.ac.uk

\section{References}

[1] P.E. Agre, Infrastructure and institutional change in the networked university, Information Communication and Society, vol. 3 np.4, pp. 494-507, 2000.

[2] I. Aitken, Value-Driven IT Management. Oxford: Butterworth-Heinemann, 2003.

[3] J.C. Anderson, and J.A. Narus, Business marketing: understanding what customers value, Harvard Business Review, November/December, vol. 76, no. 7, pp. 53-64,1998.

[4] R. Armit, and C.Zott, Value Drivers of e-Commerce Business Models, in Creating Value Winners in the New Business Environment (E. Ch, M A. Hitt, R. Amit, Ch E. Lucier, R.D. Nixon Eds.). Oxford: Blackwell Publishing, 2002, pp.15-48.

[5] A. Aurum, M. Handzic, A.Gardiner, Supporting Creativity in Software Development: An Application in IT Education, in Current Issues in IT Education, T. McGill Ed. Hershey: IRM Press, 2003, pp. 77-88.

[6] W.S. Baer, Competition and collaboration in online distance learning, Information Communication \& Society, vol. 3, no. 4, pp. 457-473, 2000.

[7] Board Briefing on IT Governance (2003), $2^{\text {nd }}$ edition, IT Governance Institute October, Rolling Meadows IL, [Online]. Available: http://www.itgi.org/ 
[8] M.H. Boisot, Knowledge Assets, Securing Competitive Advantage in the Information Economy, Oxford: Oxford University Press, 1998.

[9] C. Bowman, V. Ambrosini, Value creation versus value capture: towards a coherent definition of value in strategy, British Journal of Management, vol. 11, no. 1, pp. 1-15, 2000.

[10] T Boyle, Design principle for authoring dynamic, reusable learning objects, Australian Journal of Educational Technology, vol. 19 no. 1, pp. 46-58, 2003.

[11] J. Brase, W. Nejdl, Ontologies and Metadata for e-Learning, In Handbook on ontologies (S.Staab, and R. Studer Eds.). Berlin: Springer, 2004, pp.555-575.

[12] P. Buxmann, T. Wietzel, F. Westarp, W. Konig, The Standardization Problem - An Economic Analysis of Standards in Information Systems, in Proceedings of the 1st IEEE Conference on Standardization and Innovation in Information Technology, SIIT'99, 1999, pp.157-162.

[13] J.M. Burn, and C. Ash, Knowledge Management Strategies for Virtual Organizations, In Modern Organizations in Virtual Communities, (J. Kisielnicki Ed.). Hershey: IRM Press , 2002, pp 1-18.

[14] J.A. Byrne, The virtual corporation, Business Week, February, no 8, pp. 98-102, 1993.

[15] Y. E. Chan, IT Value: The Great Divide Between Qualitative and Quantitative and Individual and Organizational Measures, Journal of Management Information Systems, vol.16, no 4. Spring, pp. 225 - 262, 2000.

[16] R.P. Chait, W.P. Ryan, and B.E. Taylor, Governance as Leadership: Reframing the Work of Nonprofit Boards, Hoboken: John Wiley \& Sons, 2004.

[17] V. Clulow, and J. Brace-Govan, Web-Based Learning: Experience-Based Research, In Web Based Education Learning from Experience, A. K. Aggarwal Ed. Hershey: IRM Press, 2003, pp.49-71.

[18] C.M. Daily, D.R. Dalton, and A.A Cannella, Corporate Governance: Decades of Dialogue and Data, Academy of Management Review, vol. 28, no. 3, pp.371-382, 2003.

[19] V Dirksen, and B Smit, Exploring the Common Ground of Virtual Communities: Working Towards a "Workable Definition" In Modern Organizations in Virtual Communities (J. Kisielnicki Ed.). Hershey: IRM Press, 2002, pp 67-76.

[20] A. Dumort, New media and distance education, Information Communication \& Society, vol. 3 no. 4, pp. 546-556, 2000.

[21] M. Duplaga, K. Juszkiewicz, and M. Leszczuk, Telelearning Standards and their Application in Medical Education, In Transformation of Health Care with Information Technologies (M. Duplaga, K. Zielinski, and D Ingram Eds.). Amsterdam: IOS Press, 2004, pp.308-319.

[22] E Eickelmann, Defining Meaningful Measures of IT Productivity with the Balanced Scorecard, In Information Systems Evaluation Management, W. Van Grembergen Ed. Hershey: IRM Press, 2002, pp. 132-146.

[23] M. Fahy, J. Roche, and A. Weiner, Beyond governance Creating Corporate Value through Performance, Conformance and Responsibility, Chichester: John Wiley \& Sons, 2005.

[24] G. Fandel, U. Backes-Gellner, M. Schluter, and J.E. Staufenbiel, Modern concepts of the Theory of the Firm, Managing Enterprises of the New Economy, Berlin: Springer, 2002.

[25] G.F. Farrell, The Changing Faces of Virtual Education, Vancouver: The Commonwealth of Learning, 2001.

[26] U.J. Franke The Competence-based View on the Management of Virtual Web Organizations, In Modern Organizations in Virtual Communities (J. Kisielnicki Ed.). Hershey: IRM Press, 2002, pp 19-48.

[27] S. ten Have, W.S.F. ten Have, and M. van der Elst, Key management models, London: Prentice Hall, 2003.

[28] R.E. Johnson, Shareholder Value - A Business Experience, Oxford: Butterworth Heinemann, 2001.

[29] D. Johnston, E. Pan, and B. Middleton (2002) Finding the Value in Healthcare Information Technologies, Centre for Information Technology Leadership, Partners health Care, Boston MA, [Online]. Available: http://www.citl.org/findingTheValue.pdf

[30] S. Juszczyk, The pedagogical and psychological chosen problems of the on-line education, In The Fourth International Meeting on New Technologies of E-learning Systems and Network Environments, Distance Learning Workshop, Distance Learning Centre and Department of Computer Systems, Institute of Informatics at University of Silesia, Sosnowiec, 2004, pp. 61-71.

[31] R.S. Kaplan, and D.P Norton, The Balanced Scorecard: Measures That Drive Performance, Harvard Business Review, January-February, pp. 71-79, 1992.

[32] R.S. Kaplan, and D.P. Norton, The Balanced Scorecard: Translating Strategy into Action, Boston: Harvard Business School Press, 1996.

[33] J Kisielnicki, Virtual Organization as a Chance for Enterprise Development In Modern Organizations in Virtual Communities ( J. Kisielnicki Ed.). Hershey: IRM Press, 2002, pp 100-115.

[34] T. Langenberg, Standardization and Expectations, Berlin: Springer, 2006.

[35] D. Lee, J.Flyzik, M. Langston, L. Holcolmb, R. Thomas, and M.A. Tiemann (1999, September) Federal Enterprise Architecture Framework, Version 1.1, [Online]. Available: http://secure.cio.noaa.gov/hpcc/docita/files/ federal enterprise_arch framework.pdf.

[36] J.D. Lewis, and A. Weigert, Trust as a Social Reality, Social Forces, vol. 63, no. 4, pp. 967-985, 1985.

[37] H. Mintzberg, and J.B. Quinn, The strategy process. Concepts, contexts, cases, NY Englewood Cliffs: Prentice Hall, 1991.

[38] T. Mitra (2005) A case for SOA governance, [Online]. Available: http://www128.ibm.com/developerworks/webservices /library/ws-soa-govern/

[39] D. Morrison, E-learning Strategies How to get implementation and delivery right first time, Chichester: John Wiley \& Sons, 2003.

[40] M. Nentwich, Cyberscience: Modelling ICT - induced changes of the scholarly communication system in: Information Communication \& Society, vol. 8, no. 4, pp. 542-560, 2005. 
[41] R.D. Nixon, Creating Value Winners in the New Business Environment, Oxford: Blackwell Publishing, 2002.

[42] M Pankowska, Value Driven Management in e-Healthcare, In Transformation of Healthcare with Information Technology (K.Zielinskiego, M .Duplaga, and D.Ingram Eds.). Amsterdam: IOS Press, 2004, pp. 3-12.

[43] M. Pankowska, J Goluchowski, and M. Smolarek, Euromaster in e-Business and Cyber-communication - the Distance Learning Project, In Distance Learning Workshop The Fourth International Meeting on New Technologies of e-Learning Systems and Network Environments, Distance Learning Centre and Department of Computer Systems, Institute of Informatics, University of Silesia, Poland, Sosnowiec, June, 2004, pp. 41-51.

[44] M. P. Papazoglou, and P.M.A. Ribbers, e-Business Organizational and Technical Foundations, Chichester:John Wiley \& Sons, 2006.

[45] C Parolini, The Value Net A Tool for Competitive Strategy, Chichester: John Wiley \& Sons, 1999.

[46] J. Piaget, Sociological Studies, London: Routlege, 1995.

[47] R T Plant, eCommerce, Formulation of Strategy, Upper Saddle River: Prentice Hall, 2000.

[48] M Porter, Competitive Advantage, creating and sustaining superior performance, New York: The Free Press, 1995.

[49] C.K. Prahalad, and V. Ramaswamy, The Future of Competition, Co-creating Unique Value with Customers, Boston: Harvard Business School Publishing, 2003.

[50] E. Prasopoulou, A. Poulymenakou, and N. Pouloudi, Unraveling the Virtual University, In Managing Dynamic Networks (S. Klein, A. Poulymenakou Eds.). Berlin: Springer, 2006, pp 259-283.

[51] L Prusak, Knowledge in Organizations, Boston: Butterworth-Heinemann, 1997.

[52] J.F. Rayport, and J.J. Sviokla, Exploting the virtual value chain, Harvard Business Review, Nov-Dec, no. 73, pp. 75-85, 1998

[53] D.Remenyi, A.Money, and M. Sherwood-Smith, The effective measurement and management of IT costs and benefits, Oxford: Butterworth Heinemann, 2000.

[54] C. Shapiro, and H.R Varian, Information Rules, Boston: Harvard Business School Press, 1999.

[55] T. Thiadens, Manage IT! Dordrecht: Springer, 2005.

[56] A. Thompson, and A.J. Strickland, Strategic Management concepts and cases, Boston: McGrawHill Irwin, 2003.

[57] W. Van Grembergen, Strategies for Information Technology Governance, Hershey: IRM Press, 2004.

[58] R. Wagenaar, and J. Gonzalez (2003). UK Bologna Seminar, Tuning Educational Structures in Europe, The Tuning Approach A Case [Online]. Study, Available: http://odur.let.rug.nl/TuningProject/documentos/Tuning_phase1/Tuning_phase1_full_document.pdf.

[59] D. Walters, Operations Strategy, Houndmills Hampshire: Palgrave Macmillan, 2002.

[60] D. Walters, Implementing value strategy through the value chain, Management Decision, vol. 38, no. 3, pp. 160$178,2000$.

[61] T Weitzel, Economics of Standards in Information Networks, Information Age Economy, Berlin: Springer, 2004.

[62] W.F. Wright, R. Smith, R. Jesser, and M. Stupeck, Information Technology, Process Reengineering and Performance Measurement: A Balanced Scorecard Analysis of Compaq Computer Corporation, Communications of the Association for Information Systems, Vol 1. pp.1-51, 1999. 